\title{
Guiding principles and practices of peace education followed in secondary schools of Mizoram
}

\author{
Lokanath Mishra ${ }^{1}$, Tushar Gupta ${ }^{2}$, Abha Shree ${ }^{3}$ \\ ${ }^{1}$ Faculty Development Centre, Mizoram University, India \\ ${ }^{2,3}$ Department of Education, Mizoram University, India
}

\section{Article Info \\ Article history: \\ Received May 19, 2020 \\ Revised Sep 28, 2020 \\ Accepted Oct 11, 2020}

\section{Keywords:}

Guiding principles

Peace education

Secondary schools

\begin{abstract}
The significance of peace education is universally recognized for a safe and prospering future for the world at school level as peace education aims at equipping the future citizens with necessary knowledge, attitude, and skills so that they would acknowledge and respect all kinds of diversity and understand human dignity. This paper is based on an empirical research aiming how far guiding principles and practices of peace education followed in secondary schools of Mizoram. The concept of peace education, guiding principles of peace education and practices on peace-related activities being followed in the secondary schools of Mizoram were explored. The study revealed that peace education was not being taught as a separate subject. Peace education component was infused in the existing curriculum and also was being taught through co-curricular and extra-curricular activities. Besides, teachers must reflect in their behavior all the guiding principles of peace. They should encourage the students for critical thinking, reasoning, develop awareness on societal problems and issues, broaden their outlook, concentrate on studies, and to be associated with various activities. In Mizoram, students' unions and church organizations used to play a prominent role in shaping and moulding the character of the people starting from the early stage of life which ultimately benefits the society and the nation. However, in the context of rapid change in social structure and modernization process, there is need for inculcating the values of peace for which schools have to play important role.
\end{abstract}

This is an open access article under the CC BY-SA license.

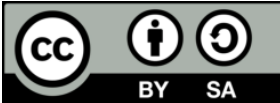

\section{Corresponding Author:}

Lokanath Mishra,

Department of Education,

Mizoram University,

Aizawl, India.

Email: munumishra7@gmail.com

\section{INTRODUCTION}

Peace education in school must be an action-oriented. It should be built practical-oriented rather than indoor study. The classroom study, no doubt, is crucial, but the action only makes a long-lasting impact. Gandhi said, our action must be a co-ordinating work of our hand, head and heart (peace). Peace education is competency-based education that empowers school children to utilize creative and non-violent means to settle down their conflicts. It will lead them to live a quality of life with harmonious development. Peace education encourages students to live peacefully with others for a greater aim of individual and collective well-being. Undaunted, everybody has to be continued on their journey of peace-building for being a responsible citizen of nation. Peace education can be defined as a tool of education that facilitates peace and harmony in society. Peace education will nurture our belief system to make positive attitude towards sense of 
intense gratification. If we consider the extant circumstances across the global perspective, the fundamental concern of peace education is to prevent the suffering and wastage of warfare.

Ian and Morrison [1] argue that "peace education refers to the teaching about peace-what is, why it doesn't exist and how to achieve it." It is a process of promoting the knowledge, skills, attitudes, and values to prevent conflict and violence [2]. Hague Appeal for Peace defines peace education as an overall participatory process that combines teaching human rights and teaching for and about democracy more dominant over other pertinent issues. Peace education as an activity that develops competency is needed to explore concepts of peace, enquire into the obstacles to peace to resolve conflicts in well-adjusted and nonviolent way, as well as to study the ways of constructing justly and sustainable alternative futures [3]. Let us teach our youths the principles of peace in our classrooms, not the principles of war. Only a peace-oriented education system and curriculum can help the nations overcome the mutual fear and distrust and bridge the gap rather than create it, and further triggered to international understanding and peace. Hence, peace education is considered as an avenue to foster the societal well-being and mental accountability of the future tiny tots who are in the schools [4]. There are several ways to introduce peace education in schools, colleges, workplaces, and community centres. The school approach and the societal approach are the two distinct approaches of peace education that can be implemented in practical $[5,6]$. The school approach to peace education, according to [6], school system serves as a vital agent of socialisation. In this study, the school approach emphasizes on utilizing the school to transform the conflictive intergroup relations within the boundary of society. The assumption of this approach is that school considered as a crucial agency of socialization. Therefore, induction of peace education at the school level can have a positive impact on the behaviour of different stakeholders that caused a ripple effect on community base [7]. However, the school approach to peace education demand some rigorous efforts such as formal training for better equipping the teachers, development of peace education-based curricula, appealing textbooks, and conducive teachinglearning environment to introduce peace education formally at school level curriculum transaction. Peace education tries to develop competence with collaborative and co-operative learning methods along with such environment where children comprehend the essence of tolerance, care and mutual respect. The underlying principles of peace education are to avoid confrontations and provide conflict resolutions at both individual and societal level for peaceful co-existence that is based on equality, tolerance and social justice.

In developing countries like India, peace education at the school level seems to have been given a back seat, though, in our social context, it is considerately relevant and demanding. It is required that serious attention need to be given for imparting peace education in our schools for developing the desired personality characteristics with the children during their formative stage [8,9]. To attain the objectives of peace education, massive changes are required such as time-suited educational objectives, revamping school curricula, developing updated instructional material, and most importantly training of teachers that makes them academically sound in the effective delivery of peace education content [10]. Further, on this take, researchers urged that teacher education programs must incorporate peace education inevitably as an integral part of their course structure. Likewise, it is arguably an effective strategy for making peace pedagogy viable for society if peace educators work with students in framing a positive and comprehensive concept of peace [11]. Besides, it becomes more substantial while developing "peace education kit" as its centrality lies on child-centred, innovative and participatory pedagogies [12]. It combines pedagogy with course content and teacher resource that is easy to use as written in simple language. Peace education program strongly influences the mind of the teachers and the students. Through this program, the students can be enlightened on the mantra of living the life of contentment. It also promotes conflict-free peaceful life that leads them prosperous future. Similarly, the teachers can also get benefitted from the short-term training program on peace education just by feeling the attitudinal changes towards life.

Voluntary standards for peace education regarded peace education as a comprehensive instruction [13]. Although the voluntary standards are a response to new liberal policies in the field of education; they were born of enduring concepts along with research on educational practice and peace development. As the international community and its various school's grapple with several types of violence, comprehensive peace education provides student preparation for responsible stewardship through an enacted vision of a better world. Peace is everyone's responsibility within any given community. Instead of focusing the training on a selected group of individuals, it is preferable to target all school children and to involve selfselected participants in the community programme.

The two most significant institutions that influence children's concept of love and hate are family and school. The constructive relationship among students can be enhanced by a co-operative learning environment, conflict resolution techniques, and dispute management cells in schools that would help them to live in a peaceful world [14]. Providing maximum opportunities of speaking and expressing their views to children which may, in turn, boost their morale courage and be part of their personality for their later life [15]. The pedagogy of experiential learning can be instrumental for enhancing the knowledge about 
peace and violence, developing ideas, motivations and skills for making this world a better place to live. They argue that experiential learning can help in reorienting the school culture towards peace, provide the youth with an opportunity to influence and educate the public, and practice conflict resolution and violence prevention programs. In their view, participants of such an experiential program enjoy the possibilities of reflecting on their position in connection with the earth, building peaceful relationships with others, and taking on responsibilities for the well-being of communities [15]. India is a vast country having around 135 billion population belonging to different race, religion, caste and region. People speak different languages, because they vary among themselves socially and culturally. Due to such differences, cultural and communal tensions occur frequently. All such pressures are the obstacles for the growth and development of our nation. India can march ahead, if the people would be able to realise the importance of peace and live in harmony. For the success of the mission of peace education, it is inevitably desired that the socio-cultural contexts of different societies are to be assessed, policies and programmes need to be formulated, imparters (teachers) also need to be trained, then only peace education can be effectively transacted. India has many diversities, particularly, geographical, socio-cultural and political. On this line of thought, research support in various contexts must be available to design curriculum framework for peace education.

The state of Mizoram, the secondary school, has been found a place where different kinds of violence are tolerated and perpetrated by the stakeholders. As per the government data, 99 children raped and registered under Protection of Children from Sexual Offences (POSCO) Act in Mizoram in 2016 while the same reported 129 in 2017 and 66 in 2018. Similarly, 27 cases of child rape found under Indian Penal Code (IPC) in 2018. Sexual assault is also reported very high in Mizoram, 74 cases registered in 2017, 40 cases in 2018 and 62 cases in 2016. Crime against women and girls were also reported in Mizoram. Twenty-three girls raped in 2016, 46 cases registered in 2017, whereas 24 cases in 2018. Molestation cases registered considerably high, i.e. 115 in 2017, 71 in 2016 and 64 in 2018. The total gross enrolment ratio (GER) of Mizoram is 21.6 in 2019 and specifically girls' GER is 21.1. Therefore, researchers wanted to identify what are the causes of low GER among girls in Mizoram [16].

Though the unrest in the north-eastern region of India had been a history of political causes, but the regional conflict is much related to multi-ethnicity. These social, political and economic conflicts among varied groups are the matter of ethnic supremacy. They are distinguished as they tend to be asymmetrical, ambiguous and tough to differentiate between associates and opponent, fought unconventionally using political and psychological means and methods. These conflicts often develop into a protracted war of attribution. Mizoram is one of the north-eastern states of our country which has followed the path of peace from its inception as an independent State of India in 1987 for its development and is marching ahead, after a long period of insurgency. It was desired that the State should continue to follow the path of peace and goodwill. This will be possible when the peace values and civilized culture prevail among the citizens. Though there is a number of studies conducted by the researchers [12,17-20] across the world, but no such comprehensive study has been conducted in India who focussed on the peace education practices in secondary school system. However, National Curriculum Framework (NCF)-2005 and National Curriculum Frame Work for Teacher Education (NCFTE)-2014 highlighted about peace education in secondary schools and one optional paper in teacher education programme has also been introduced but the findings of this study are having utmost importance in local context. Since peace is always related to socio-cultural and political factors, one study in such context may not be sufficed to draw any inference for all situations (National Curriculum framework Review, 2005). The secondary school students are the future of transformative society and global citizenry. It is imperative to inculcate the values of peace so that, the culture of peace would prevail in all walks of life among the students. Hence, there is a dire need to explore how far the concept of peace education, guiding principles of peace education and practices on peace-related activities being followed in the secondary schools of Mizoram.

\section{RESEARCH METHOD}

The study was of a mixed methods research in nature in which secondary school students and teachers of Mizoram were the target population. The total sample of the study comprised of 200 students, 100 boys and 100 girls of class IX, 100 teachers from 20 government secondary schools of Mizoram. Students were selected on simple random sampling procedure, five teachers from each school (two science two arts and one physical education teacher) were selected purposively for the present study. For the present study, it was decided to use a questionnaire and interview as the techniques of data collection. The questionnaire was structured and developed in simple English, which can be easily comprehended by the class IX and X students. Focus Group Discussions (FGD) [10] were held in the schools to collect relevant information from the teachers and students. First, the researcher identified the 20 sample schools based on the locality and region, i.e. ease, west south and north. The researcher establishes the rapport with the concerned headmaster 
of the school. With the help of the headmaster, the researcher selected the students and teachers of the concerned school. The questionnaire was administered to them and collected the data on the same date. The FGD was held in the four-district headquarters with the help of the headmasters. The data were analyzed both qualitatively and quantitatively. Simple percentage was employed for analysis of quantitative data and classical content analysis was used to analyze the FGD data.

\section{RESULTS AND DISCUSSION}

Majority of the sampled students $(78 \%)$ and teachers $(72 \%)$ opined that the guiding principles of peace like equality of all, the dignity of others; liberty of all; security in the school; justice for all; nonviolence practices; sharing responsibility; cooperation among students, teachers and parents; democratic principles; human rights; environment-friendly behaviour; cultural diversity; and sustainable development were being respected and followed in their schools [21]. Seventy-four per cent sampled students and sixtyfive per cent teachers expressed that morning prayer, the celebration of important national and international days, and celebration of birthdays of great personalities used to be organized in the schools. But, activities like peace club, peace march, peace poster competition, discussion on social issues, the arrangement of extramural lecturers, organization of essay and debate competitions, the establishment of peace museum, practice of yoga, film show, creation blogs in social media, community participation, organization of street play and drama either were not organized or rarely organized. In the FGD, it is found that morning prayer was not used to be organized daily in many schools, national and international days and birthdays of great personalities used to be celebrated only as notified by the higher authorities.

Seventy-eight per cent of the sampled students and teachers expressed that values like respect for others, practising non-violence, forgiveness and reconciliation, justice and equality, conflict resolution, environmental protection, promotion of democratic values, secular attitude, development of ideal citizenship, promotion of national integration and international understanding, cultural identity and acculturation and socialization need to be emphasized in the secondary schools of Mizoram for promoting peace culture among students [22].

Sixty-three per cent of the respondents expressed that personality characteristics like respect to humanity, empathy, compassion for all creatures, self-discipline, and tolerance were not duly emphasized with the secondary school students of Mizoram. But, qualities like honesty, truthfulness, cleanliness, positive thought, charity, gentleness, modesty, patience, straightforwardness, and altruism used to be emphasized with them $[15,23]$.

Seventy-six per cent of the secondary school teachers of Mizoram were not aware of the concept of peace education. All the sampled secondary school teachers felt the dire need of imparting peace education in secondary schools of Mizoram. Peace education was not being taught as a separate subject, but its components were infused in the existing curriculum and also was being taught through co-curricular and extra-curricular activities. In the FGD, it is found that teachers must act as role models for students in propagating peace and also specific training on peace education is felt essential for in-service secondary school teachers. Seventy-two per cent teachers said that teachers must reflect all the guiding principles of peace in their behaviour, i.e. equality of all, the dignity of others, liberty of all, justice for all, non-violence practices, sharing responsibility, co-operation and harmony among teachers, and between teachers and parents, democratic principles, human rights values, environment-friendly behaviour, tolerance and respect to cultural diversity, and sustainable development. Teachers should also show compassion, empathy, discipline, and proper manners and follow professional ethics. Teachers should encourage the students for critical thinking, to develop awareness on societal problems, broaden their outlook, concentrate on studies, and to be associated with various activities[24].

The Mizo society knit together by culture, values and religious faith; that is why they can play a more significant role in inculcating peace values among students as suggested by the respondent teachers. Through different non-governmental organizations, it can prohibit divorce which is rampant, impose dress code for girls, organize youth awareness camps to inculcate essential values, insist on maintaining cultural ethics and respecting human rights, maintain objectivity and impartiality in local and village councils, support and co-operate government in the implementation of welfare policies, rules and regulations, discourage mob rules, and eradicate social evils [25]. The society can keep a vigilant eye on the activities of the school students. Some other measures, like mass meetings, can be organized through different forums to promulgate the justly consonance of peace, non-violence and community participation. On this line of thought, peace volunteers can be selected for this noble cause in every locality and peace preacher centre can be established to spread the peace message through sharing of knowledge and information [26-28].

Mizoram is a peaceful State, and the people here live in harmony without any violence in society. For better promotion of peace values among the secondary school students, the following suggestions are 
offered based on the feedback received from the stakeholders. The teaching of peace-related concepts can be delivered in five stages, namely engage, explore, explain, elaborate and evaluate (5Es). The first stage of engagement is aimed to start the $5 \mathrm{E}$ constructivist model of teaching in a classroom setting with the involvement of students in learning activities (problem introduction, for example, violence). After engaging students, the second stage of exploration provides an opportunity to students for accessing the necessary information and resources to define the concept of violence. After exploration, explanation stage demand to explain the concept learnt in the earlier stage and present the method of problem-solving, here it is how to deal with the violence problem in different circumstances. The peace education curriculum with civic and moral instruction can serve as an essential instrument in encouraging peace education for moral rearmament [29]. The fourth stage of elaboration is considered for higher-level cognitive functioning or extended abstraction. The final evaluation stage determines the extent of learning through various strategic activities.

Teachers should be oriented with the right kind of pedagogy to handle peace-related contents through in-service programs. The school administration and teachers are to be encouraged to develop aptitude and attitude towards peace education as effective delivery of curriculum can phenomenally serve the community in particular and society at large. The state government should take stringent measures on drug trafficking and prevent corruption [30]. Competent government authorities can take the initiative to involve all the stakeholders such as school administrators, teachers, parents and communities to support the implementation and promotion of peace education in the highest good.

\section{CONCLUSION}

The underlying philosophy of peace education is to teach love, compassion, trust, fairness, cooperation and reverence for all life. Teachers must ensure the culture of peace in the schools, and they must project themselves as role models of peace. They must resolve any issue and conflict among themselves, and amongst students through dialogue. In the light of twenty-first-century challenges, pedagogy of peace education became critical and viable. It is not taught as a separate paper but to incorporate fewer aspects of peace-related content. The concept like peace-families, peace-society, peace-initiatives taken up by UNO, UNESCO, Young Men's Christian Association (YMCA), Young Women's Christian Association (YWCA), Red Cross, Scout and guides. In present global order, secondary school curriculum pertinently must include the literature on pioneer of this field, Noble peace laureates, repercussions of war and crime as well as orient students with different peace movements across the globe. The state government can establish peace clubs and self-defence training centres in all secondary schools of Mizoram as a highly acclaimed gesture towards promoting peace education.

\section{ACKNOWLEDGEMENTS}

The author thanks all participating secondary school teachers and students in this study for their full co-operation in conducting this research.

\section{REFERENCES}

[1] Harris, Ian M. and Mary Lee Morrison, Peace Education. McFarland \& Company, Inc., Publishers: North Carolina, USA, 2003

[2] UNICEF, "The Peace Education Working Group in UNICEF," 1999.

[3] F. Schmidt and A. Friedman, "Peace making skills for little kids," Miami Beach, Peace Education Foundation, 1988.

[4] A. S. Balasooriya, Learning the Way of Peace, A Teacher's Guide to Peace Education. United Nations Educational, Scientific and Cultural Organization, New Delhi, 2001.

[5] B. Kaur, Peace Education. New: Elegant Printers New Delhi, 2006.

[6] D. Bar Tal, "The elusive nature of Peace Education," In G. Salomon \& B. Nevo (Eds.), Peace Education: The concepts, principles, and practices around the world. Mahwah, NJ: Lawrence Erlbaum Associates, 2002.

[7] D. Bar-Tal and Y. Rosen, "Peace Education in Societies Involved in Intractable Conflicts: Direct and Indirect Models," Review of Educational Research, vol. 79, no. 2, pp. 557-575, 2009.

[8] Mishra, L., "Strengthening Peace Education in Secondary School Curriculum," International Journal of Education for Peace and Development, vol. 1, no. 1, pp. 1-6, 2013.

[9] Mishra. L, "Designing a peace education programme for secondary schools," Journal of Research in Peace, Gender and Development, vol. 1, no. 4, pp. 155-160, 2011.

[10] Mishra, L., "Focus Group Discussion in Qualitative Research," TechnoLearn: An International Journal of Educational Technology, vol. 6, no. 1, pp. 1-5, 2016. 
[11] Brock-Utne, Educating for Peace: A Feminist Perspective. New York: Pergamon Press, 1996. [Online]. Available: https://www.jstor.org/stable/424391

[12] Bretherton, Weston, and Zbar, "School-Based Peace Building in Sierra Leone," Theory into Practice, vol. 44, no. 4 , pp. 355-362, 2010.

[13] Carter, C.C., Standards for Peace Education, 2010. [Online]. Available: http://www.unf.edu/thefloridacenter/ PeaceEdStdsForWebsite.pdf

[14] Deutsch, M., "Educating for Peaceful World," American Psychologist, vol. 48, no. 5, pp. 510-517, 1993.

[15] Salomon, G., The nature of Peace Education: Not all programs are created equal. In G. Salomon \& B. Nevo (Eds.), Peace education: The concept, principles, and practices around the world. Lawrence Erlbaum Associates Publishers, pp. 3-13, 2002.

[16] Government of Mizoram Statistical Abstract of Mizoram, Directorate of Economics \& Statistics, Government of Mizoram, 2017.

[17] Begum, A., "The concept and perception of peace education in Gilgit Baltistan Pakistan: A comparative case study," The Peace and Conflict Review, vol. 7, no. 1, pp. 25-39, 2012.

[18] Mishra, L., "Implementing Peace Education in Secondary Schools of Odisha: Perception of Stake Holders," Sakarya University Journal of Education, vol. 5, no. 2, pp. 47-54, 2015.

[19] Reardon, Betty, Comprehensive Peace Education. Educating for Global responsibility. New York: Teachers College Press, 1998.

[20] National Curriculum framework Review, National Focus Groups Positive Papers. Draft: Education for Peace. New Delhi: National Council of Educational Research and Training, 2005.

[21] Mary Adada, "Effectiveness of Peace Education Programmes in Secondary Schools: A Case Study of Kisumu Municipality, Kenya," International Journal of Liberal Arts and Social Science, Vol. 4, No. 2, pp. 28-41, 2016.

[22] Jean de Dieu Basabose, "Peace Education in Rwandan Secondary Schools: Coping with Contradictory Messages," Journal of peace building, vol. 14, no. 2, pp. 138-149, 2019.

[23] Buhigiro, J. L., Wassermann, J., The experiences of Rwandan history teachers in teaching the genocide against the Tutsi as a controversial issue, 2017. [Online]. Available: www.genocideresearchhub.org.rw

[24] Sarkar SR., "Peace Situation among the Students of Secondary Level in West Bengal," Arts and Social Sciences Journal, vol. 7, no. 6, pp. 1-4, 2016.

[25] Cristian Gordillo, "Peacebuilding in Colombia: teachers' and students' perspectives on the Lectures on Peace," Journal of Peace Building, vol. 8, no. 2, 2020. [Online]. Available: https://doi.org/10.1080/21647259.2020. 1731124

[26] Adebajo, A., "Foreword: Three Prophets of Pax Africana," In The Palgrave Handbook of Peacebuilding in Africa, T. Karbo and K. Virt (Eds). Cham: Palgrave Macmillan, 2018.

[27] Alamu, A. G. "Exploring Indigenous Religious Tenets for Democratic Sustainability in Contemporary Nigerian Society," In Democracy, Good Governance and Development in Africa, M. Mawere and T. R. Mwanaka (Eds). Mankon, Bamenda: Langaa Research \& Publishing CIG, pp. 213-232, 2015.

[28] Amenga-Etego, R. M., “Akokobere Nso Nim Adekyee': Women's Interpretation of Indigenous Oral Texts," In Unravelling and Reweaving Sacred Canon in Africana Womanhood, R. E. Ross and R. M. Amenga-Etego (eds). Lanham: Lexington Books, pp. 3-19, 2015.

[29] Arowosegbe, J. O., "Indigenous African Jurisprudential Thoughts on the Concept of Justice: A Reconstruction through Yoruba Proverbs," Journal of African Law, vol. 61, no. 2, pp. 155-170. 2017.

[30] Mishra L., "Strengthening Peace Education in Secondary School Curriculum," International Journal of Education for Peace and Development (IJEPD), vol. 1, no. 1, pp. 1-6, 2013. 